\title{
Pengaruh Ekstrak Kulit Jeruk Nipis \\ (Citrus Aurantifolia Swingle) Konsentrasi 10\% Terhadap Aktivitas Enzim Glukosiltransferase Streptococcus mutans
}

\author{
Zenia Adindaputri U.*, Nunuk Purwanti**, dan Ivan Arie Wahyudi** \\ *Pendidikan Dokter Gigi Fakultas Kedokteran Gigi Universitas Gadjah Mada \\ **Bagian Biomedika Fakultas Kedokteran Gigi Universitas Gadjah Mada \\ **Jl. Denta No. 1 Sekip Utara No 1 Yogyakarta, e-mail: pedrobernado.pb@gmail.com
}

\begin{abstract}
ABSTRAK
Streptococcus mutans merupakan bakteri yang berperan sebagai agen utama penyebab karies gigi, yang memiliki enzim glukosiltransferase (GTF). Enzim GTF akan mengubah sukrosa menjadi fruktosa dan glukan. Salah satu herbal tradisional yang dapat berperan sebagai antibakteri adalah kulit jeruk nipis (Citrus aurantifolia Swingle) yang mengandung polifenol terutama flavonoid. Tujuan penelitian ini untuk mengetahui pengaruh ekstrak kulit jeruk nipis (Citrus aurantifolia Swingle) konsentrasi 10\% terhadap aktivitas enzim GTF Streptococcus mutans. Penelitian ini menggunakan ekstrak kulit jeruk nipis konsentrasi $10 \%$ sebagai perlakuan, chlorhexidine gluconate $0,12 \%$ sebagai kontrol positif, serta akuades steril sebagai kontrol negatif. Metode penelitian ini terdiri dari tiga tahap yaitu penyiapan ekstrak kulit jeruk nipis konsentrasi 10\%, penyiapan enzim GTF dari supernatan Streptococcus mutans, dan pengujian aktivitas enzim GTF melalui analisis konsentrasi fruktosa dengan menggunakan High Performance Liquid Chromatography (HPLC). Pembacaan luas area fruktosa dilakukan berdasarkan waktu retensi. Satu unit aktivitas enzim GTF di definisikan sebagai $1 \mu$ mol fruktosa/ml dari enzim/jam. Selanjutnya data yang diperoleh dianalisis secara statistik dengan one way ANOVA. Hasil perhitungan aktivitas enzim GTF dengan one way ANOVA menunjukkan perbedaan yang signifikan antara kelompok perlakuan dengan kelompok kontrol negatif $(p<0,05)$, dan tidak terdapat perbedaan yang signifikan dengan kontrol positif. Kesimpulan dari penelitian ini adalah ekstrak kulit jeruk nipis konsentrasi 10\% dapat menghambat aktivitas enzim glukosiltransferase Streptococcus mutans.
\end{abstract}

Maj Ked Gi; Desember 2013; 20(2): 126-131.

Kata kunci: Streptococcus mutans, glukosiltransferase, kulit jeruk nipis (Citrus aurantifolia Swingle)

\begin{abstract}
The Influence of 10\% Concentrate of Citrus Aurantifolia Swingle on The Activities of Streptococcus Mutans Glucocyl Transferase Enzyme. Streptococcus mutans is a bacteria which has glucosyl transferase (GTF) enzyme and acts as the main agent that causes dental caries. GTF enzyme will convert sucrose into fructose and glucan. Lime peel (Citrus aurantifolia Swingle) is one of the traditional herbs which has flavonoid as an antibacterial agent. The purpose of this research is to investigate the effect of $10 \%$ concentration of lime peel extract (Citrus aurantifolia Swingle) to the activity of GTF enzyme Streptococcus mutans. This research used $10 \%$ concentration of lime peel extract as the treatment, $0.12 \%$ chlorhexidine gluconate as a positive control, and distillate water as a negative control. The method of this research consists of three steps; preparing the lime peel extract concentration of $10 \%$, preparing the GTF enzyme from the supernatant of Streptococcus mutans, and testing GTF enzyme activity by analyzing the fructose concentration using High Performance Liquid Chromatography (HPLC). Perusal of the fructose area was based on the retention time of fructose. One unit of GTF enzyme activity is defined as the $1 \mu \mathrm{mol}$ fructose / $\mathrm{ml}$ of enzyme / hour. The obtained data then were analyzed by one way ANOVA. The result showed a significant difference between treatment group with the negative control $(p<0.05)$, and there are no significant difference with the positive control. This research concludes that $10 \%$ lime peel extract can inhibit the GTF enzyme activity of Streptococcus mutans.
\end{abstract}

Maj Ked Gi; Desember 2013; 20(2): 126-131.

Keywords: streptococcus mutans, glucosyltransferase, lime peel extract (citrus aurantifolia swingle) 


\section{PENDAHULUAN}

Karies gigi ditandai kerusakan lokal jaringan gigi berupa demineralisasi email dan dentin gigi akibat dari asam yang diproduksi oleh mikroorganisme plak sebagai hasil samping dari fermentasi karbohidrat. ${ }^{1}$ Bakteri penyebab utama karies gigi adalah Streptococcus mutans yang merupakan bakteri gram positif berbentuk kokus dan merupakan flora normal pada rongga mulut manusia. ${ }^{2}$ Streptococcus mutans menghasilkan polisakarida ekstraseluler yang larut dan tidak larut seperti glukan dan fruktan dari sukrosa yang berhubungan dengan pembentukan plak dan kariogenitas. $^{3}$

Streptococcus mutans menghasilkan enzim glukosiltransferase (GTF) yang dapat mengubah sukrosa menjadi glukan, dan merupakan faktor virulensi utama Streptococcus mutans. ${ }^{3}$ GTF merupakan enzim yang mempunyai dua domain fungsional. Domain pertama memiliki suatu aktivitas glucan synthesizing dan domain kedua merupakan suatu glucan binding domain. ${ }^{2}$

Penghambatan GTF baik yang terlarut maupun yang terserap pada permukaan gigi sebagai salah satu upaya mencegah karies gigi serta beberapa penyakit periodontal yang diakibatkan oleh adanya plak gigi. ${ }^{4}$ Glukosiltransferase merupakan faktor yang sangat penting dalam kemampuan Streptococcus mutans untuk menimbulkan karies gigi. Enzim GTF dapat dideteksi dalam supernatan kultur. $^{5}$

Jeruk nipis (Citrus aurantifolia Swingle) termasuk salah satu jenis Citrus (jeruk) yang mengandung unsur-unsur senyawa kimia yang bemanfaat, misalnya: asam sitrat, asam amino (triptofan, lisin), minyak atsiri (sitral, limonen, felandren, lemon kamfer, kadinen, gerani-lasetat, linali-lasetat, aktilaldehid, nonildehid), damar, glikosida, asam sitrun, lemak, kalsium, fosfor, besi, belerang vitamin B1 dan C. Selain itu, jeruk nipis juga mengandung senyawa saponin dan flavonoid yaitu hesperidin (hesperetin 7-rutinosida), tangeretin, naringin, eriocitrin, eriocitrocid. ${ }^{6}$

Kulit buah jeruk nipis juga memiliki peran penting bagi kesehatan. Kulit jeruk nipis mengandung komponen yang sangat bermanfaat untuk menurunkan kadar kolesterol. ${ }^{7}$ Kulit buah jeruk nipis mengandung senyawa flavonoid yaitu naringin, hesperidin, naringenin, hesperitin, rutin, nobiletin, dan tangeretin. ${ }^{8}$ Flavonoid merupakan golongan terbesar dari senyawa polifenol yang dapat bekerja sebagai antioksidan, ${ }^{7}$ dan juga sebagai antibakteri dengan mendenaturasi protein sel bakteri dan merusak sel bakteri. ${ }^{9}$ Flavonoid juga dapat menghambat aktifitas GTF dari Streptococcus mutans. ${ }^{4}$ Tujuan penelitian ini untuk mengetahui pengaruh ekstrak kulit jeruk nipis (Citrus aurantifolia Swingle) konsentrasi 10\% terhadap aktivitas enzim GTF Streptococcus mutans.

\section{METODE PENELITIAN}

Bahan yang digunakan adalah ekstrak kulit buah jeruk nipis (Citrus aurantiifolia Swingle) konsentrasi $10 \%$, enzim GTF Streptococcus mutans, aquades steril, sukrosa 0,25 $\mathrm{M}$, bufer fosfat 0,2 M pH 7, larutan standar fruktosa dan sukrosa, Chlorhexidine digluconate $0,12 \%$.

Alat yang digunakan adalah mesin penyerbuk, Homogenizer, Vacum rotary evaporator, Waterbath, Cawan porselin, corong Buchner, Ose, Lampu spiritus, Tabung reaksi, Conical tube, Inkubator, Shaker, Centrifuge, Micropipete, Tabung eppendorf, Kertas saring filter milipore 0,45 $\mu \mathrm{m}$, HPLC (High Performance Liquid Chromatography).

Penyiapan Ekstrak Kulit Jeruk Nipis. Pembuatan ekstrak kulit jeruk nipis dilaksanakan di Laboratorium Penelitian dan Pengujian Terpadu (LPPT) Universitas Gadjah Mada. Jeruk nipis yang digunakan adalah jeruk yang sehat, berwarna hijau kekuningan. Kulit buah jeruk nipis dikeringkan kemudian diserbuk. Serbuk kulit buah jeruk nipis dimaserasi menggunakan alkohol 70\%. Hasil maserasi dibuat ekstrak dengan menguapkan pelarut menggunakan vacuum rotary evaporator, kemudian diencerkan menjadi konsentrasi 10\%

Penyiapan Enzim GTF. Bakteri Streptococcus mutans diperoleh dari laboratorium Mikrobiologi Fakultas Kedok-teran Hewan Universitas Gadjah Mada. Bakteri Streptococcus mutans diinokulasikan ke dalam botol media pembiakan yang berisi 10 $\mathrm{ml} \mathrm{BHI}$ cair, kemudian diinkubasi pada suhu $37^{\circ} \mathrm{C}$ selama 24 jam. Sesudah kultivasi selama 24 jam, 
media kultur digetarkan dengan shaker $150 \mathrm{rpm}$ kemudian disentrifugasi $1500 \mathrm{rpm}$ selama 30 menit dan akan diperoleh supernatan yang mengandung enzim GTF. ${ }^{10}$

Pengujian Aktivitas Enzim GTF. Pengujian dilakukan di Laboratorium Kimia dan Biologi Pusat Studi Pangan dan Gizi Universitas Gadjah Mada. Sembilan tabung reaksi disediakan pada penelitian ini, tiga tabung pertama untuk kontrol posisitf, tiga tabung selanjutnya untuk kontrol negatif dan tiga tabung berikutnya untuk perlakuan. Kelompok perlakuan dan kontrol diberi campuran $0,9 \mathrm{ml}$ sukrosa 0,25 $\mathrm{M}$ dalam bufer fosfat $0,2 \mathrm{M} \mathrm{pH} \mathrm{7,}$ ditambahkan $0,1 \mathrm{ml}$ larutan enzim GTF, ekstrak kulit jeruk nipis konsentrasi $10 \%$ sebanyak 0,025 $\mathrm{ml}$ (volume yang sama untuk chloherxidine 0,12\% sebagai kontrol positif dan aquades steril sebagai kontrol negatif) ditambahkan buffer fosfat $0,2 \mathrm{M} \mathrm{pH}$ 7 sampai volume total $2 \mathrm{ml}$. Semua bahan perlakuan dan kontrol tersebut diinkubasikan pada suhu $37^{\circ} \mathrm{C}$ selama 2 jam.

Sesudah diinkubasi dan disaring dengan kertas saring $0,45 \mu \mathrm{m}$, konsentrasi fruktosa diuji dengan High Performance Liquid Chromatography (HPLC), yaitu dengan menyuntikan $20 \mu$ larutan perlakuan atau larutan kontrol, kemudian dilihat waktu retensinya. Untuk menghitung kadar fruktosa dipergunakan rumus yang diperoleh melalui pembacaan luas area fruktosa pada larutan standar fruktosa sebagai berikut: ${ }^{11}$

Konsentrasi Fruktrosa $=\frac{\frac{A C}{A S} \times \frac{V i s}{V i c} \times F P}{K S} \times 100 \%$

\section{Keterangan :}

$A C=$ Area contoh / area sample

Vic $=$ Volume injek contoh

AS $=$ Area standar

$\mathrm{KS}=$ Konsentrasi standar

Vis = Volume injek standar

$\mathrm{FP}=$ Faktor pengenceran contoh
Satu unit aktivitas enzim GTF didefinisikan sebagai $1 \mu \mathrm{mol}$ fruktosa / ml dari enzim / jam. ${ }^{12}$ Data yang diperoleh selanjutnya dimasukkan ke dalam tabel dan dianalisis secara statistik melalui uji beda rerata sampel menggunakan uji one way ANOVA.

\section{HASIL PENELITIAN}

Hasil uji larutan standar fruktosa konsentrasi 2500 ppm pada HPLC menunjukkan bahwa waktu retensi untuk fruktosa berada pada kisaran menit ke 12,053 (Gambar 1) sehingga luas area fruktosa sampel yang dihasilkan dapat dilihat dari waktu retensinya yang akan tertera pada hasil kromatogram. Hasil penelitian menunjukkan bahwa kadar tertinggi fruktosa terdapat pada kontrol negatif, sementara kadar fruktosa paling rendah terdapat pada kontrol positif. Hal ini menunjukkan bahwa pada kontrol negatif memiliki aktivitas enzim GTF paling tinggi, sedangkan kontrol positif memiliki aktivitas enzim GTF paling rendah (Tabel I dan Gambar 2).

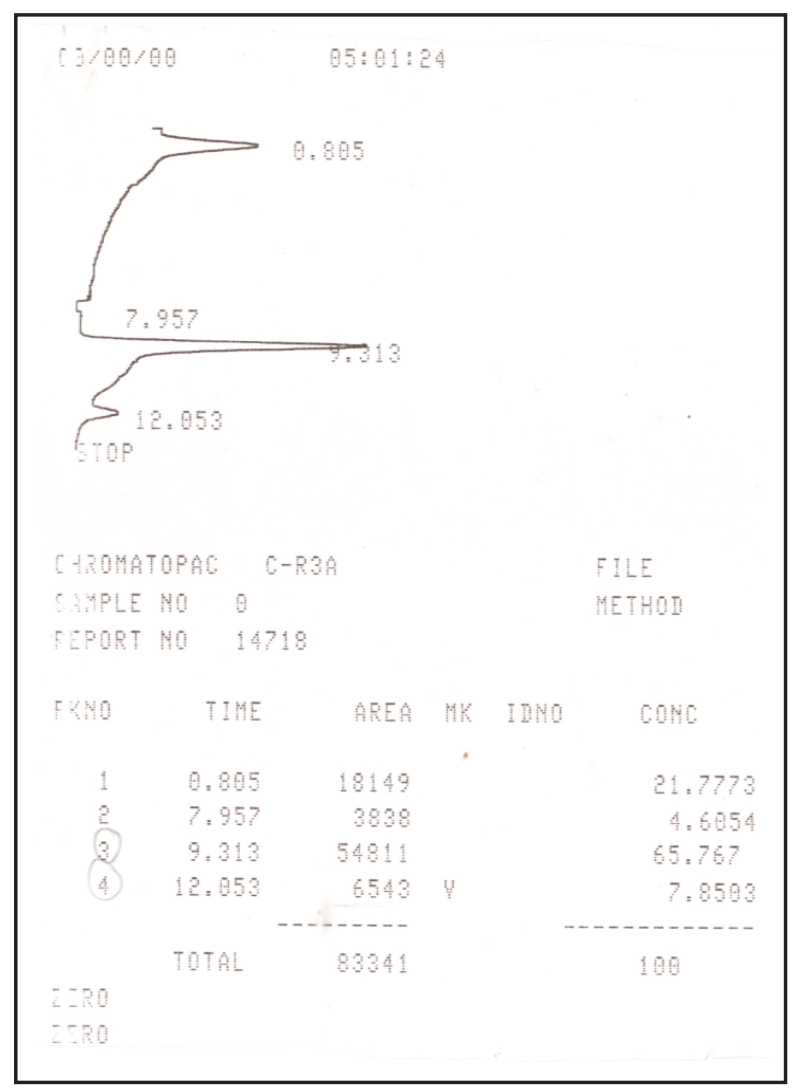

Gambar 1. Hasil Kromatogram Standar Sukrosa dan Fruktosa 
Hasil data yang diperoleh dari penelitian ini berskala rasio dengan jumlah kelompok perlakuan lebih dari 2 dan tidak berpasangan sehingga untuk menganalisis data secara statistik dilakukan uji analisis parametrik one way ANOVA.

Tabel 1. Rerata dan standart error aktivitas enzim glukosiltransferase setelah pemberian perlakuan dengan ekstrak kulit jeruk nipis 10\%, kontrol positif, dan kontrol negatif

\begin{tabular}{cccc}
\hline No & \multicolumn{1}{c}{ Perlakuan } & $\mathrm{n}$ & \multicolumn{1}{c}{$\overline{\mathrm{x}} \pm$ SE } \\
\hline 1 & Kontrol positif & 3 & $2,29 \pm 2,293$ \\
2 & EKJN 10\% & 3 & $8,12 \pm 4,489$ \\
3 & Kontrol negartif & 3 & $25,96 \pm 6,801$ \\
\hline
\end{tabular}

\section{Keterangan:}

$\mathrm{n} \quad=$ jumlah sampel

$\mathrm{x} \quad=$ rerata aktivitas enzim GTF

SE $=$ Standart Error

EKJN = Ekstrak Kulit Jeruk Nipis

Hasil uji normalitas menunjukkan nilai signifikansi sebesar 0,143 ( $p>0,05)$. Hasil uji tersebut menyatakan bahwa data terdistribusi normal.
Hasil uji homogenitas variansi menunjukkan angka signifikansi 0,197 ( $p>0,05$ ), hasil ini menunjukkan bahwa variansi data dari tiap sampel yang diuji adalah sama (homogen). Setelah itu dilakukan uji one way ANOVA.

Berdasarkan hasil uji one way ANOVA didapatkan nilai signifikansinya adalah 0,033 ( $\mathrm{p}<$ 0,05), sehingga dapat disimpulkan bahwa terdapat perbedaan bermakna aktivitas enzim GTF antar perlakuan. Selanjutnya untuk mengetahui pada kelompok perlakuan mana yang memiliki perbedaan rerata yang bermakna, dilakukan uji lanjutan yaitu dengan uji analisis Post-Hoc LSD (Least Significant Difference). Hasil uji LSD dapat dilihat pada Tabel 2.

Tabel 2. Hasil Uji LSD aktivitas enzim GTF Streptococcus mutans

\begin{tabular}{lccc}
\hline Perlakuan & $\begin{array}{c}\text { Kontrol } \\
(+)\end{array}$ & $\begin{array}{c}\text { EKJN } \\
10 \%\end{array}$ & Kontrol (-) \\
\hline Kontrol (+) & & 0,432 & $0,014 *$ \\
EKJN 10\% & & $0.042 *$ \\
Kontrol (-) & & \\
* Kelompok perlakuan dengan beda rerata yang \\
signifikan
\end{tabular}

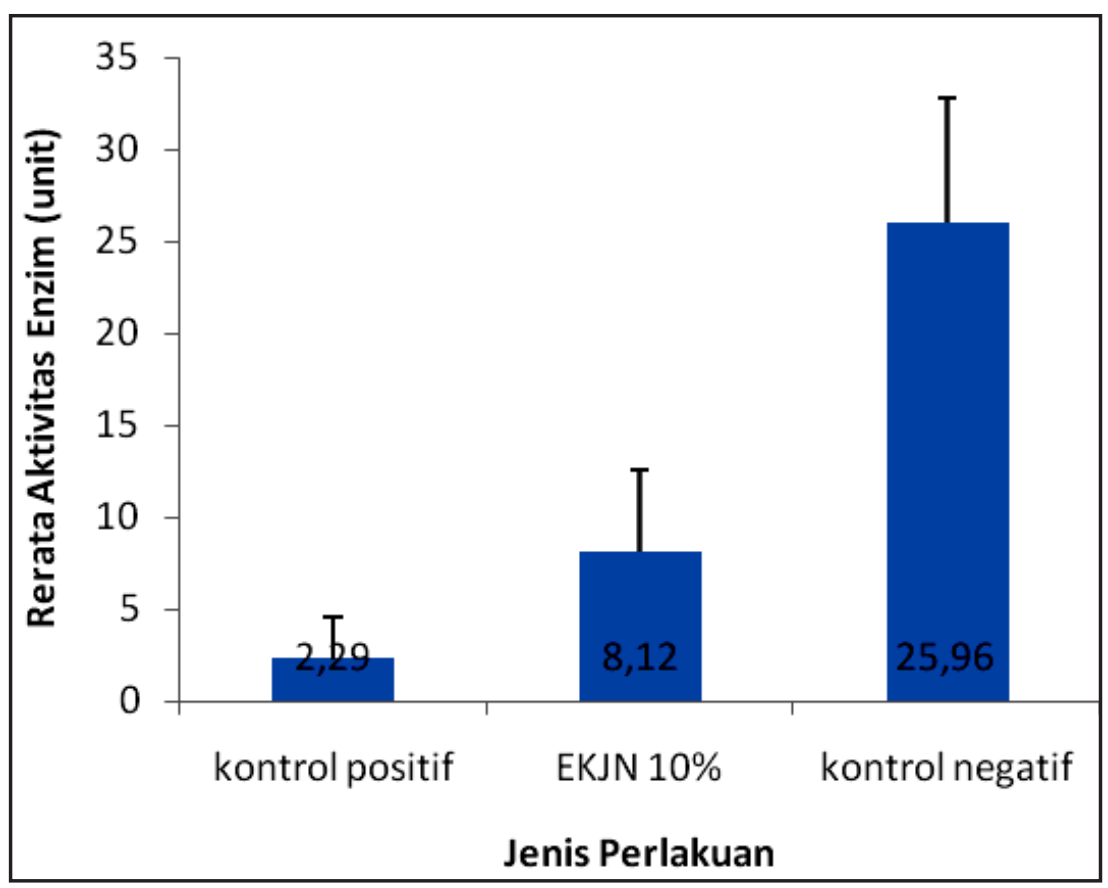

Gambar 2. Grafik rerata aktivitas enzim glukosiltransferase (unit) 


\section{PEMBAHASAN}

Hasil penelitian menunjukkan enzim GTF Streptococcus mutans pada kontrol negatif memiliki nilai tertinggi dibanding kelompok perlakuan lainnya yang secara kualitatif dapat dilihat dari kadar fruktosa yang dihasilkan paling banyak dibanding perlakuan lainnya. Hal ini dikarenakan pada kontrol negatif larutan pada tabung eppendorf berisi sukrosa, bufer fosfat, enzim GTF, dan akuades yang bersifat netral dan tidak memiliki daya hambat terhadap enzim GTF, sehingga enzim GTF yang terdapat dalam larutan dapat mengkatalisis perubahan sukrosa menjadi fruktosa dalam jumlah banyak.

Aktifitas enzim GTF dalam mengubah sukrosa menjadi fruktosa dan glukan dapat dihambat oleh senyawa - senyawa tertentu seperti polifenol yang didapat pada tanaman herbal seperti pada ekstrak tanaman rosemary dan teh oolong. ${ }^{13,14}$ Kulit jeruk nipis dalam penelitian ini terbukti dapat menghambat aktivitas enzim GTF Streptococcus mutans. Penelitian sebelumnya telah diketahui bahwa kulit jeruk nipis mengandung senyawa polifenol terutama flavonoid. ${ }^{8}$

Flavonoid merupakan turunan fenol yang mempunyai kemampuan dalam merusak protein. ${ }^{15}$ Flavonoid mempunyai ikatan rangkap antara atom $C$ nomor 2 dan atom $C$ nomor 3 yang akan bereaksi dengan gugus amina pada enzim GTF sehingga akan mengikat gugus tersebut dan merusak enzim GTF. ${ }^{4}$ Oleh karena itu, enzim yang tersusun dari sebagian besar protein dapat didenaturasi oleh ekstrak kulit jeruk nipis.

Hasil penelitian menunjukkan bahwa ekstrak kulit jeruk nipis dapat menghambat aktivitas enzim GTF secara signifikan. Terdapat perbedaan yang bermakna antara perlakuan ekstrak kulit jeruk nipis $10 \%$ dengan kontrol negatif.

Sebagai kontrol positif pada penelitian ini digunakan chlorhexidine 0,12\%. Berdasarkan hasil penelitian, diketahui bahwa nilai rata - rata aktivitas enzim GTF lebih rendah dari perlakuan yang lain (Tabel 1). Dapat diartikan bahwa chlorhexidine memiliki daya hambat terhadap enzim GTF yang lebih baik daripada perlakuan ekstrak kulit jeruk $10 \%$ dan kontrol negatif.
Chlorhexidine adalah bahan aktif antibakteri yang cukup baik dibanding dengan agen antibakteri lainnya, selain itu chlorhexidine juga dapat menghambat aktivitas enzim GTF.16,17,18 Chlorhexidine pada konsentrasi bakteriostatik akan bekerja menghambat enzim membran dan mengacaukan interaksi antara lipid dan protein dalam membran. ${ }^{19}$ Oleh karena itu chlorhexidine akan bekerja menghambat enzim GTF Streptococcus mutans dan mendenaturasi protein enzim tersebut. Akan tetapi selain bersifat antibakteri dan dapat menghambat aktivitas enzim GTF, chlorhexidine memiliki efek samping secara lokal saat digunakan sebagai obat kumur yaitu dapat menyebabkan perubahan warna pada gigi, restorasi, dan gigi tiruan, sehingga dibutuhkan bahan herbal lain yang tidak menyebabkan efek samping. ${ }^{16}$

\section{KESIMPULAN}

Ekstrak kulit jeruk nipis (Citrus aurantifolia Swingle) konsentrasi $10 \%$ dapat menghambat aktivitas enzim glukosiltransferase (GTF) Streptococcus mutans.

\section{DAFTAR PUSTAKA}

1. Samaranayake LP, Jones BM. Essential microbiology for dentistry. Ed 2. London: Churchill. Livingstone; 2002. H. 217-8.

2. Lamont RJ, Burne RA, lantz MS, LeBlanc DJ. Oral microbiology and immunology. Washington D.C: ASM Press; 2006. H. 233-7.

3. Marsh P, Martin MV. Oral microbiology. 4th ed. Oxford: Wright; 1999. H. 17-22, 44-50.

4. Koo H, Rosalen PL, Cury JA, Park YK, Bowen $W H$. Effects of compounds found in propolis on streptococcus mutans growth and on glucosyltransferase activity. Antimicrob Agents Chemother. 2002. 46(5): 1302-9

5. Fujiwara T, Hoshino T, Ooshima T, Sobue S, Hamada S. Purification characterization, and molecular analysis of the gene encoding Glucosyltransferase from Streptococcus oralis. Infect Imun. 2000. 68(5): 2475-83. 
6. Adina AB, Handoko FF, Setyarini II, Septistyani EP, Riyanto S, Meiyanto. Ekstrak etanolik kulit jeruk nipis (Citrus aurantifolia (cristm.) Swingle) meningkatkan sensitivitas sel mcf-7 terhadap Doxorubicin. Proceeding Kongres IImiah XVI Ikatan Sarjana Farmasi Indonesia. 2008; 55-62.

7. Astawan W, Kasih AL. Khasiat Warna - Warni Makanan. Jakarta: PT Gramedia Pustaka; 2008. H. 31,101

8. Choi SY, Ko HC, Ko SY, Hwang JH, Park JG, Kang $\mathrm{SH}$, Han SH, Yun SH, Kim SJ. Correlation between flavonoid content and the no production inhibitory activity of peel extracts from various citrus fruits. Biol. Pharm. Bull. 2007; 30(4): 772-8

9. Pelczar MJ, Chan ECS. Dasar-dasar mikrobiologi 2(terj). Jakarta: UI Press; 1988. H. 504

10. Ikeno K. Ikeno T, Miyazawa C. Effect of propolis on dental caries in rats. Caries Res. 1991: 25: 347-51

11. Putriyanti D. Identifikasi fruktosa pada beberapa jenis tape serta pengamatan perubahan mikrobiologi dan biokimiawi tape singkong selama fermentasi. Skripsi. Bogor: Fakultas Teknologi Pertanian Institut Pertanian Bogor; 1990.

12. Park YK, Koo MH, Abreu JAS, Ikegaki M, Cury JA, Rosalen PL. Antimicrobial activity of propolis on oral microorganisms. Curr Microbiol. 1998; 36: $24-8$.

13. Po-Jung $T$, Tzung-Hsun $T$, Su-Chen $H$. In vitro inhibitory effects of rosemary extracts on growth and glucosyltransferase activity of streptococcus sobrinus. Food Chemistry. 2007; 105: 311-6.

14. Nakahara K, Kawabata S, Ono H, Ogura K, Tanaka T, Ooshima T, Hamada S. Inhibitory effect of oolong tea polyphenols on glucosyltransferase of mutans streptococci. Appl Environ Microbiol. 1993; 59(4): 968-73.

15. Jawetz E, Melnick JL, Adelberg EA. Mikrobiologi Untuk Profesi Kesehatan edisi 16. Jakarta: EGC; 1986. H. 115.

16. Fejerskov O, Kidd E. Dental Caries: The Disease and Its Clinical Management. Ed 2. Oxford: Blackwell Munksgaard; 2008. H. 271

17. Scheie AAA, Kjeilen JCJ. Effects of chlorhexidine, $\mathrm{NaF}$ and S11F2 on glucan formation by salivary and culture supernatant GTF adsorbed to hydroxyapatite. Scand J Dent Res. 1987; 95: 532-5 .

18. Furiga A. Dols-Lafargue M, Heyraud A, Chambat G, Lonvaud-Funel A, Badet C. Effect of antiplaque compounds and mouthrinses on the activity of glucosyltransferases from streptococcus sobrinus and insoluble glucan production. Oral Microbiol Immunol. 2008; 23: 391-400.

19. Anonim. Chlorhexidine compounds in cosmetic products: Risk assessment of antimicrobial and antibiotic resistance development in microorganisms. 2010. http://www.vkm.no/dav/10b449dcc5.pdf, (9 April 2012). 